Relations industrielles

Industrial Relations

\title{
Slomp, Hans, Between Bargaining and Politics: An \\ Introduction to European Labor Relations
}

\section{Michael Poole}

Volume 52, numéro 4, 1997

URI : https://id.erudit.org/iderudit/051209ar

DOI : https://doi.org/10.7202/051209ar

Aller au sommaire du numéro

Éditeur(s)

Département des relations industrielles de l'Université Laval

ISSN

0034-379X (imprimé)

1703-8138 (numérique)

Découvrir la revue

Citer ce compte rendu

Poole, M. (1997). Compte rendu de [Slomp, Hans, Between Bargaining and Politics: An Introduction to European Labor Relations]. Relations industrielles / Industrial Relations, 52(4), 891-982. https://doi.org/10.7202/051209ar

Tous droits réservés (C) Département des relations industrielles de l'Université Laval, 1997
Ce document est protégé par la loi sur le droit d'auteur. L'utilisation des services d'Érudit (y compris la reproduction) est assujettie à sa politique d'utilisation que vous pouvez consulter en ligne.

https://apropos.erudit.org/fr/usagers/politique-dutilisation/ 


\title{
Recensions
}

\section{Book Reviews}

\author{
Between Bargaining and Politics: An Introduction to European Labor \\ Relations \\ by Hans SLOMP, Westport, Connecticut and London: Praeger, 1996, 165 p., \\ ISBN 0-275-95608-3.
}

This volume comprises an interesting and well-informed account of European labour relations. It serves its purpose well as an introductory text. Its historical emphasis and level of detail are, moreover, particularly valuable attributes and help to make the book very well worth reading.

The first point made by Slomp is that there are certain basic features of European labour relations. The first is that collective bargaining is coordinated by industry and sector and frequently involves employers' associations. Second, company bargaining and worker participation in enterprise decision-making are different (and worker participation can therefore be practised without undue conflict). And third national governments are involved in labour relations in a variety of ways partly by legislation on bargaining, conflict and worker participation but also by the regulation of working conditions and the monitoring of wage bargaining.

Nonetheless, Slomp also recognizes the diversity within Europe and hence distinguishes three models of labour relations :

(1) The British model (also applying to Ireland)

(2) The German model (including Germany, the Low Countries and the Alpine Countries) and

(3) The Latin European model of France and Southern Europe
Moreover, there is some discussion in the text of a fourth "Central European" pattern.

The more detailed analysis then develops with an account of corporatism. Indeed, "tripartite" relations between trade unions, employers' associations and national governments are arguably what is so distinctive about most of European labour relations. Furthermore, Slomp distinguishes three types of corporatism (p. 8) : union-employer based versus government - steered corporatism; corporatism based on labour's strength versus corporatism based on a weak labour movement; and social versus liberal corporatism.

In Chapter 2 the linkages between trade unions, employers, parties and politics (based on the three models of European labour relations) are assessed. The origins of British unionism in a craft (and work-place) tradition is thus contrasted with industrial unionism on the European continent. Moreover, the role of employers' associations and the links to politics are examined.

A valuable aspect of this study is the historical emphasis and, in Chapter 3, a series of major historical steps are outlined. These include: industrialism and craft unionism (1848-1880); the emergence of social democracy (1890-1910); the rise of communism (1917-1920); crisis, war and reconstruction (1930$1950)$; the golden sixties (1960-1974); and Central Europe under communism. 
This is a prelude to the analysis, in Chapter 4 , of labour relations and politics in the 1990s. The account includes the role of technology, de-industrialization, changes in gender in the workplace and the rise in the number of "foreign" workers. Other issues addressed encompass the decline of Keynesianism, the end of dictatorship and the demise of communism in Latin Europe.

In Chapter 5, the importance of multiemployer bargaining in European labour relations is addressed and it is linked with models of conflict in various parts of Europe. More specifically, issues associated with the public sector (and its relative decline) are also examined. The importance of worker participation (and particularly of works councils) to European industrial relations are addressed in Chapter 6 . Again this is a major unifying theme of much of European labour relations that makes European models so different from those of North America and Japan.

Modern developments in Europe are then highlighted in the ensuing chapters. Above all, the movement from sector bargaining to enterprise diversity accompanying the decentralization of collective bargaining is developed as a key recent trend. Labour conditions in Europe (wages, working time, health and safety, social insurance, and employment and employment protection) are examined in Chapter 8. Moreover, the fundamental issues raised for European labour relations from the European Union are featured in Chapter 9. And, in this respect,
Slomp (p. 126) concludes that: "For a long time to come, Europe will continue to be a patchwork of nation states with national systems of labor relations. Only with great difficulty can they be grouped together into a British, a Germanic and a Latin model in order to show common European trends as well as major European cleavages."

Finally, there are two somewhat idiosyncratic chapters. First of all pairs of nations (Denmark and Norway, Belgium and Holland, Austria and Switzerland, Portugal and Spain and Hungary and Poland) are contrasted. And last of all there is "a summary in American terms."

In evaluation, this study can be recommended as an introductory text. To be sure, there is little here of a theoretical nature (e.g., on forces for convergence or divergence). The structure of the book could have been tighter. The groups of countries identified are somewhat difficult to defend (e.g., Ireland as opposed to Britain has largely continued with tripartism). Some of the major worldwide developments which have so much affected industrial relations (such as the rise of the multinationals) receive only a cursory examination. And, as indicated earlier, the last two chapters fit uneasily into the structure of the overall book. But it is interesting and, above all, the historical detail helps to make the book a valuable one.

MICHAEL POOLE Cardiff Business School, UK

What Do We Need A Union For? The TWUA in the South, 1945-1955

by Timothy J. MINCHIN, London and Chapel Hill : University of South Carolina Press, 1997, 285 p., ISBN 0-8078-4625-2

C. Vann Woodward once noted that the history of the American South is one of benign neglect. Professions of nationalism from "new south" historians have fed into tacit assumptions that the mean- ing of the South can be adequately covered by integrating its unique history into the general contours of the national story, with a cursory reference to the region's perverse sectionalism, composed of an 